\title{
Dinamika Kelembagaan Sektor Pariwisata di Kabupaten Ponorogo
}

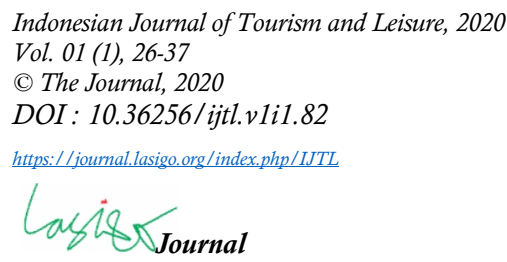

Received: February $28^{\text {th }}, 2020$

Revised: March 23 ${ }^{\text {rd }}, 2020$

Accepted :March 28 $8^{\text {th }}, 2020$

\section{Yusuf Adam Hilman}

Universitas Muhammadiyah Ponorogo, Jawa Timur

adam_hilman@umpo.ac.id

\section{Titing Kartika}

STIEPAR YAPARI Bandung, Jawa Barat

nengtiting_kartika@yahoo.co.id

\begin{abstract}
Ponorogo regency has a variety of tourism resources, potentially developed to increase the tourism sector. This study aims to analyze the strategy of Ponorogo regency in governing the tourism sector based on strength, weakness, opportunity, and threat (SWOT). Using descriptive qualitative approach, this research was conducted in Ponorogo regency. The results indicate that Ponorogo has various tourism sources, such as nature, culture, art, religion, and gastronomy, as the strength. The weakness is that there are many tourism events not well managed by the government. The opportunity is extensive funding support from the government. The threat is the conflict in managing government grants. In addition, the government of Ponorogo regency is successful in delivering 66 tourism ceremonies using local regulation in order to change the threat to be the strength.
\end{abstract}

Keywords: Tourism; SWOT Analysis; Tourism Potency; Event

\begin{abstract}
ABSTRAK
Kabupaten Ponorogo memiliki berbagai potensi pariwisata, yang berpeluang untuk dikembangkan dalam rangka meningkatkan sektor pariwisata. Tujuan Penelitian ini adalah untuk menganalisis strategi Kabupaten Ponorogo dalam mengelola sektor pariwisata. Dengan menggunakan pendekatan deskriptif-kualitatif, penelitian ini dilakukan di Kabupaten Ponorogo. Hasil Penelitian ini memperlihatkan bahwa Ponorogo memiliki banyak potensi pariwisata, seperti keadaan alam, kebudayaan, seni, kepercayaan, dan gastronomi, sebagai sebuah kekuatan. Kelemahannya adalah banyaknya kegiatan wisata yang belum dikelola dengan baik oleh pemerintah setempat. Peluangnya adalah besarnya dukungan dana dari pemerintah. Ancamannya adalah rawan potensi konflik dalam pengaturan dana dari pemerinatah. Selain itu, Pemerintah Kabupaten Ponorogo sukses menyelenggarakan 66 kegiatan wisata dengan mengeluarkan peraturan daerah guna mengubah ancaman menjadi kekuatan.
\end{abstract}

Keywords: Pariwisata; Analisis SWOT; Potensi Pariwisata, Aktifitas Wisata

Corresponding Author

Name : Yusuf Adam Hilman

Email : adam_hilman@umpo.ac.id 


\section{Pendahuluan}

Pakar Ekonomi Indonesia Rizal Ramli berpendapat bahwa perekonomian di Indonesia dalam kondisi tidak baik, atau bisa dikatakana sakit. Hal ini disebabkan oleh Indek Harga Saham Gabungan (IHSG) yang terus anjlok, para konglomerat perusahaan tidak mau membeli surat utang korporasi karena dinilai tidak menguntungkan. Kondisi ini kemudian menyebabkan banyak aliran dana lari ke luar negeri, kemudian berpengaruh pada nilai tukar rupiah yang semakin naik (detik.com, 2018b). Kondisi melemahnya nilai rupiah, pada perjalanan sepertujuh di tahun 2018, telah memberikan gambaran terkait kondisi perekonomian Indonesia saat ini. Pemerintah harus berupaya dengan cepat dan tepat melalui langkah strategis untuk kembali menguatkan nilai mata uang rupiah yang melemah dikarenakan banyaknya aliran modal lari keluar negeri. Tindakan seperti peningkataan dalam sektor penerimaan negara di sektor non migas dan juga non pajak sangat penting, mengingat kedua sektor tersebut pada dasarnya akan melahirkan kebijakan yang tidak populis bagi pemerintah, karena tidak disukai oleh masyarakat.

Penerimaan Negara dari sektor migas dan pajak selama ini merupakan sektor unggulan yang menyumbang devisa Negara terbesar, akan tetapi karena kebijakan ekonomi dari kedua sektor tersebut, sepertinya sulit digenjot karena iklim perekonomian dunia sedang bergejolak akibat kebijakan ekonomi USA dan juga China yang sedang melakukan kontra strategi. Efeknya, Negara berkembang seperti Indonesia menjadi kelimpungan. Menteri keuangan Sri Mulyani menyebutkan, jika realisasi penerimaan pajak pada tahun 2017 mencapai 91,0\% tertinggi angkanya dibandingkan dnegan 2 (dua) tahun terakhir, yakni mencapai kisaran angka $83 \%$. Jumlah tersebut terbilang sebesar Rp 1.339,8 triliun, meningkat dibandingkan dengan tahun 2016 yakni sekitar 4,3\% (detik.com, 2018a). Optimalisasi pajak dan sektor migas untuk mendongkrak penerimaan Negara, efeknya akan sangat berat jika dirasakan oleh Negara Indonesia, karena dua raksasa dunia sedang bergejolak, yakni United States of America dengan Republik Rakyat China (RRC). Kondisi inilah yang disinyalir mempengaruhi kondisi perekonomian Indonesia, dan berdampak langsung terhadap kekuatan ekonomi masyarakatnya.

Situasi ekonomi dan perdagangan global yang tidak menentu, ternyata sangat dipengaruhi oleh 2 (dua) negara adikuasa, yakni Amerika Serikat dan China. Kondisi tersebut berpengaruh terhadap negara-negara berkembang, terutama di kawasan Negara-negara (ASEAN) termasuk Indonesia yang memiliki hubungan kemitraaan yang erat pada sektor perdagangan dengan RRC. Perkembangan kondisi ini membuat resah, ketika muncul pernyataan dari Presiden Amerika Serikat yang akan menaikan tarif pajak barang-barang China yang masuk ke Amerika. Konflik yang terjadi antara AS dan Cina, mengakibatkan anjloknya jumlah permintaan atas produkproduk yang dibuat oleh negara-negara ASEAN di Cina. Hal tersebut kemudian memunculkan kekhawatiran jika negara-negara ASEAN akan kebanjiran besi dan alumunium dari Cina yang seharusnya dapat diekspor ke Amerika. Pada akhirnya, kondisi tersebut akan memicu turunnya harga komoditas barang dan mengancam eksistensi produsen lokal di negara-negara ASEAN. termasuk Indonesia (okezone.com, 2018).

Kondisi ekonomi yang dialami oleh Indonesia, perlu segera dicari solusi konkritnya, sehingga masalah tersebut tidak berlarut-larut, dan segera bangkit dari kondisi yang tidak menguntungkan, sehingga mampu kembali ke titik normal seperti sediakala. Satu hal yang mungkin bisa dilakukan adalah memperkuat ekonomi di level lokal melalui kelembagaan desa, dimana masyarakat bisa memberdayakan wilayahnya, sehingga dapat memberikan efek yang luas kepada masyarakat lokal. Apabila akar rumput sehat dan kuat, maka akan menimbulkan kemandirian yang secara kumulatif dapat berpengaruh terhadap perekonomian nasional Indonesia. Model pengembangan pariwisata, merupakan pilihan tepat untuk dijadikan sebagai salah satu alternatif dalam rangka peningkatan perekonomian masyarakat. Beberapa kajian menjelaskan bahwa program pariwisata sangat tepat untuk meningkatkan kemandirian bangsa 
(Firdaus \& Tutri, 2017), karena level pelaksanaan yang dilakukan pada tataran masyarakat lokal yakni di wilayah desa.

Pitana mengemukakan bahwa dampak pariwisata terhadap kondisi ekonomi dikategorikan dalam 8 kategori seperti berikut: 1). Dampak terhadap penerimaan devisa, 2). Dampak terhadap pendapatan masyarakat. 3). Dampak terhadap kesempatan kerja, 4). Dampak terhadap distribusi manfaat atau keuntungan. 5). Dampak terhadap kepemilikan dan kontrol (ekonomi) masyarakat. 6). Dampak terhadap pembangunan pada umumnya, 7). Dampak terhadap pendapatan pemerintah (Hermawan H, 2016). Regulasi menyebutkan bahwa Pariwisata berperan penting dalam aktifitas ekonomi, memberikan kesan positif, serta meningkatkan kesejahteraan masyarakat. Hal tersebut dapat dilihat dari kontribusi sektor pariwisata dalam menyumbang penerimaan devisa negara, bertambahnya Produk Domestik Bruto, kesempatan membuka lapangan pekerjaan, sebagaimana tertuang dalam Rencana Pembangunan Jangka Panjang (Pralina \& Sujali, 2009).

Kunjungan wisatawan pada tahun 2007 berjumlah 5.506 dan naik pada tahun 2008 menjadi 6.234 atau naik sekitar 13,2\%. Jumlah kunjungan kembali naik sekitar 1,4\% menjadi 6.324 juta pada tahun 2009, namun pada tahun 2009 Indonesia hanya mampu menyerap sekitar $0,72 \%$ dari jumlah kunjungan turis dunia. Hal ini sangat disayangkan adalah tidak bertambahnya pendapatan devisa dari sektor pariwisata. Pendapatan devisa tercatat pada tahun 2007 mencapai US\$5.346 juta, meningkat sekitar 38,0\% menjadi US\$7.378 pada tahun berikutnya, namun pada tahun 2009 turun sekitar 14,4\% menjadi US\$6.318 juta (Nizar, 2015). Data tahun 2013 menunjukan jika peningkatan produk pariwisata Indonesia meningkat, hal tersebut bisa dilihat dari jumlah kunjungan pada tahun 2013 sekitar 3,70 juta kunjungan, meningkat sekitar 9,96\% pada tahun yang sama (Hermawan H, 2016).

Efek domino dari pengembangan sektor pariwisata sepertinya harus dimaksimalkan, mengingat hal tersebut sangat menjanjikan jika dikelola secara baik karena efeknya bisa dirasakan langsung oleh masyarakat. Berangkat dari pengembangan potensi pariwisata, sangat memungkin jika daerah dijadikan sebagai garda terdepan dalam pengembangan wisata. Mengingat daerah memiliki potensi yang bisa dijadikan sebagai destinasi dan obyek wisata. Kabupaten Ponorogo merupakan salah satu daerah yang menjadi bagian dari provinsi Jawa Timur, Kabupaten ini memiliki luas $1.371,78 \mathrm{~km}^{2}$. Ponorogo memiliki banyak potensi pariwisata yang dapat dikembangkan, salah satu sektor yang dapat di kembangkan yakni pariwisata budaya. Agenda wisata yang merupakan kebudayaan lokal diantaranya adalah Larung sesaji di telaga Ngebel, Grebeg Suro, dan kirab pusaka. Selain itu kabupaten ini memiliki potensi lain seperti wisata alam, kuliner dan juga religi (Astuti \& Kusumawati, 2018).

Selain potensi budaya, Kabupaten Ponorogo juga memiliki potensi wisata alam selain telaga Ngebel, diantaranya Air Terjun Plethuk dan Taman Wisata Ngembag. Selain itu, fasilitas pendukung juga sangat memadai dan bisa di kembangkan menjadi salah satu alternatif wisata yang baik, namun demikian, masih banyak kelemahan di beberapa hal, seperti fasilitas kebersihan dan juga atraksi pendukung (Rahman \& Prakoso, 2012). Potensi wisata alam di Kabupaten Ponorogo sangat menjanjikan disamping potensi wisata budaya yang sangat terkenal yakni Reyog. Dalam perkembangannya kesenian ini dilembagakan melalui even pariwisata berjudul Grebeg Suro dengan ragam kegiatan wisata. Diuakini, kegiatan ini dapat meningkatkan pendapatan asli daerah, membuka kesempatan pekerjaan, dan tentunya merupakan bagian dari pelestarian budaya (Khoirurrosyidin, 2018).

\section{Kerangka Teori}

Konsep pariwisata saat ini lebih menekankan pada industri yang berbasis citra, dikarenakan citra dapat membawa serta mengarahkan calon wisatawan ke dunia simbol dan juga makna (Siahaan, 2008). Pendapat lain menyatakan pariwisata sebagai sebuah rangkaian aktifitas melalui gerakan manusia untuk melakukan perjalanan, atau sekedar singgah dari sebuah tempat ke beberapa 
tujuan di luar lingkungan tempat tinggal dengan maksud tertentu tanpa orientasi keuntungan (Zakaria \& Suprihardjo, 2014). Aktifitas wisata bukan merupakan hal yang baru di Indonesia, aktifitas ini merupakan salah satu kebijakan nasional yang sudah ada sejak Indonesia melakukan kebijakan pembangunan. Pemerintah Indonesia sadar jika pariwisata adalah aktifitas yang multidimensi dengan karakteristik yang khas, dengan bidang-bidang yang berbeda (Yuli, 2011). Aktivitas Pariwisata merupakan kegiatan yang sangat unik, mengingat aktivitas ini jika diselenggarakan secara baik, maka akan menimbulkan multiple effect yang akan membantu menambah penerimaan negara, atau secara sederhana dapat meningkatkan harkat dan martabat masyarakat.

Kebijakan pariwisata memberikan pengalaman berkesan bagi wisatawan atau pengunjung yang datang ke objek wisata. Pengalaman tersebut kemudian akan memberikan keuntungan berupa profite kepada para stekholder. Kebijakan pariwisata berfungsi sebagai kerangka yang menjadi dasar untuk penggerak pariwisata dengan tujuan: 1). Menentukan aktifitas dan perilaku yang diharapkan. 2). Memberikan arahan (direction) dan bimbingan untuk semua stekholder pariwisata di destinasi. 3). Memfasilitasi kesepakatan bersama atas dasar strategi dan tujuan yang spesifik untuk destinasi tertentu. 4). Memberikan kerangka untuk diskusi bagi publik atau swasta tentang peran dan kontribusi dari sektor pariwisata pada ekonomi masyarakat secara umum, 5). Memungkinkan pariwisata bisa berhadapan bersama dengan sektor-sektor ekonomi lain (Hidayat, 2011).

Industri pariwisata secara sederhana merupakan media yang efektif dalam upaya peningkatan kemajuan ekonomi bagi masyarakat lokal maupun global. Pariwisata juga dapat memberikan dampak dan manfaat yang banyak, antara lain menghasilkan devisa negara dan memperluas lapangan kerja. Sektor pariwisata juga bertujuan menjaga kelestarian alam dan mengembangkan budaya lokal (Anggraeni, 2013). Pengembangan pariwisata yang baik dan benar harus mempertimbangkan aspek sosial, ekonomi saat ini dan masa yang akan datang. Ukuran keberhasilanya bisa dilihat dari minimnya dampak positif dan tingginya partisipasi dalam pembentuan kegiatan pariwisata sehingga terukur dengan jelas (Hermawan, 2016a).

Kebijakan yang berhasil ditentukan oleh komunikasi, sumber daya, disposisi dan struktur birokrasi yang saling terkait dan mendukung secara kelembagaan (Jupir, 2013). Keberhasilan dalam penyelenggaraan agenda pariwisata tidak terlepas dari kekuatan kelembagaan yang dilakukan antar lini dalam melakukan sinergitas dan saling melengkapi dalam pengembangan pariwisata lokal (Hilman, 2017). Pengelolaan kelembagaan pariwisata memerlukan komunikasi antar stekholder supaya bisa mencapai tujuan bersama (Kuhaja, 2014).

\section{Metode}

Penelitian ini dilakukan di Kabupaten Ponorogo dengan pendekatan deskriptif melalui proses pengumpulan data primer dan sekunder. Data primer dikumpulkan melalui wawancara dan data sekunder dikumpulkan melalui studi dokumen hasil penelitian dan artikel jurnal. Dipilihnya pendekatan kualitatif karena penelitian ini menitikberatkan pada analisi deskriptif bukan melalui angka-angka sebagaimana diisyaratkan dalam penelitian kualitatif (Pramudita \& Herdiana, 2012). Dipilihnya Kabupaten Ponorogo sebagai lokasi penelitian dengan pertimbangan kebijakannya yang mencanangkan tahun 2019 sebagai tahun kunjungan wisata. Pada tahun tersebut Pemerintah Kabupaten Ponorogo menggeliatkan sektor pariwisata dengan melibatkan semua elemen masyarakat dan juga stekholder dalam mengembangkan potensi wisata, dan juga menyelenggarakan berbagai iven yang jumlahnya mencapai 66 acara dalam kurun waktu 1 (satu) tahun.

Penelitian deskriptif ini menggunakan data primer dan sekunder yang diperoleh dari hasil observasi, wawancara dan dokumentasi, melalui kajian literatur sesuai dengan kebutuhan data di lapangan. Analisis terhadap data lebih menekankan pada penjelasan-penjelasan data yang sudah terkumpul, dilakukan secara deskriptif, dan interpretatif sesuai dengan model penelitian kualitatif 
(Pontoh, 2011). Metode analisis data yang digunakan adalah metode analisis deskriptif kualitatif, yaitu teknik analisis yang menjelaskan data-data yang bersifat kualitatif (Kadir W, Nurhaedah, \& Purwanti, 2013; Yoserizal \& Yudiatmaja, 2010). Data-data yang dianalisis berupa hasil wawancara, hasil penelitian dan juga hasil dokumentasi yang dikumpulkan oleh peneliti.

Tabel 1. Analisis SWOT

\begin{tabular}{|l|l|l|}
\hline $\begin{array}{l}\text { Faktor Eksternal } \\
\text { (External Factors) }\end{array}$ & $\begin{array}{l}\text { Faktor Internal } \\
\text { (Internal Factor) }\end{array}$ & $\begin{array}{l}\text { Kelemahan } \\
\text { Keaknes) } \\
\text { (Strengths) }\end{array}$ \\
\hline Peluang (Opportunities) & Strategi Kekuatan - Peluang (S-O) & Strategi Kelemahan - Peluang (W-O) \\
Ancaman (Threats) & Strategi Kekuatan - Ancaman (S-T) & Strategi Kelamahan - Ancaman (W-T) \\
\hline
\end{tabular}

Sumber : Flamin \& Asnaryati, 2013

Metode ilmiah dalam proses analisis data dilakukan melalui tahapan verifikasi data, klasifikasi data, tabulasi data, dan kemudian intepretasi data untuk menghasilkan kesimpulan untuk menjawab masalah penelitian (Kristin \& Salam, 2016). Proses penelitian yang dilakukan meliputi beberapa tahapan, yakni 1) Identifikasi masalah, 2) Identifikasi potensi pariwisata di Kabupaten Ponorogo, 3) Membuat kesimpulan. Analisis SWOT digunakan dalam penelitian ini untuk mengetahui bagaimana keberlangsungan masa depan destinasi pariwisata di Kabupaten Ponorogo., Dengan menggunakan matrik SWOT diharapkan bisa memetakan sejauhmana peluang dan juga kekuatan pariwisata di kabupaten ponorogo (Flamin \& Asnaryati, 2013).

\section{Hasil dan Pembahasan}

\subsection{Potensi Pariwisata Ponorogo}

Kabupaten Ponorogo memiliki banyak sekali potensi yang dapat dikembangkan untuk aktifitas wisata, mulai dari potensi kesenian, budaya, religius, alam, hingga gastronomi. Potensi tersebut merupakan anugrah yang dimiliki oleh kabupaten yang menjadi asal kesenian reyog, potensi alam yang dimiliki berupa telaga, bukit, pegunungan, air terjun, serta gundukan batu yang secara alamiah membentuknya. Potensi budayanya sangat beragam mulai dari kesenian Reog yang menjadi primadona, karena hampir setiap desa memiliki kelompok Reog yang biasa dimainkan dengan jumlah personel yang banyak. Kabupaten Ponorogo juga memiliki kuliner khas, yaitu sate ayam khas ponorogo dan juga Dawet Jabung. Keduanya adalah perpaduan kuliner khas Jawa yang sangat cocok jika dinikmati bersama keluarga. Potensi wisata religius juga bisa dilihat dari bangunan Masjid yang menjadi bagian dari proses masuknya Islam di Bumi Ponorogo. Sebagai bagian sejarah masyarakat yang disebarkan oleh Kiai Muhammad Hasan, sebagai salah satu tokoh yang juga merupakan keturunan dari ulama-ulama besar di Pulau Jawa. Melihat potensi tersebut bisa menjadi semacam kekuatan dalam upaya pengembangan wisata lokal di Kabupaten Ponorogo.

Ponorogo sangat identik dengan kesenian Reog karena menjadi ikon budaya masyarakat lokal. Kesenian ini sangat unik dan dalam perkembangannya mampu bertahan dan terpelihara hingga saat ini. Eksistensinya bisa terjaga karena ketersediaan alat, bahan, serta properti yang mendukung kesenian tersebut. Salah satu komponen utamanya yakni "Dhadhak Merak"yang merupakan topeng yang dihiasi dengan bulu-bulu burung merak yang sangat indah. Dhadak Merak kemuduian dipanggul oleh sosok kepala harimau atau barongan dengan bobot berkisar 45- 
70 kilogram (Aliyah, Nugroho, \& Yudana, 2014). Reog Ponorogo memiliki asul-usul dari tiga cerita yang selalu menyertainya, yaitu versi Bantarangin, versi Suryangalam, dan versi Batara Katong. Yang paling sering ditemui adalah versi Suryangalam yang bersetting tempat pada era kerjaan Majapahit dengan pemimpinnya yang bernama Raja Bhre Kertabumi (Brawijaya V). Raja tersebut melakukan kritik terhadap kondisi Majapahit yang rapuh (Ikawira, Fianto, \& Sutrisno, 2014).

Selain Reog Pnorogo, terdapat Grebeg Suro, agenda tahunan yang biasa dilakukan oleh masyarakat Ponorogo setiap tanggal 1 Muharram atau 1 Suro pada penanggalan Jawa. Sebagai kegiatan rutin masyarakat yang terus melestarikan nilai-nilai luhur yang di wariskan secara turun - temurun. Dalam kegiatan tersebut terdapat rangkaian pertunjukan Reyog yang menjadi kesenian khas wilayah Ponorogo (Hanif, 2012). Kesenian ini terus berkembang dan telah menjadi identitas lokal. Seiring perjalanan waktu, kesenian Reog tumbuh dengan berbagai varian yang dikemas dalam berbagai agenda promosi wilayah. Tujuannya untuk meningkatkan kehidupan ekonomi masyarakat dan menambah pendapatan daerah. Beberapa kajian menyebutkan jika Festival Reog Ponorogo berpotensi meningkatkan perekonomian masyarakat dan pendapatan daerah (Pujiati \& Hatmawan, 2017).

Potensi tersebut sudah berhasil dikembangkan oleh Pemerintah Kabupaten Ponorogo selama bertahun-tahun. Namun demikian, jika hanya mengandalkan pariwisata dari sektor budaya saja akan sulit karena Kabupaten Ponorogo memiliki potensi alam yang melimpah yang dapat dioptimalkan dalam rangka pengembangan wilayah. Oleh karena itu, Ponorogo bisa menjadi salah satu wilayah unggulan Jawa Timur dalam bidang pariwisata.

Kabupaten Ponorogo telah mempersiapkan diri dalam rangka pengembangan Kawasan Selingkar Wilis. Kabupaten Ponorogo juga telah menyiapkan infrastruktur yang bisa digunakan sebagai embrio untuk pengembangan kawasan tersebut, mulai dari sarana jalan serta potensi wisata yang ada. Selain itu, itu peran SKPD terkait juga sangat diharapkan meskipun banyak kendala yang dihadapi oleh mereka. Kendala tersebut terutama kesamaan program kerja. Efektivitas kerjasama antar daerah dalam rangka pengembangan Kawasan Selingkar wilis ini juga harus ditingkatkan lagi, diman keenam kabupaten harus mempunyai persepsi yang sama dan satu suara. Masih adanya ketidaksamaan persepsi menjadi kendala yang dihadapi dalam program pengembangan kawasan ini. Keberadaan masyarakat lokal sebagai subjek merupakan salah satu kunci dalam rangka keberhasilan kegiatan pemerintah daerah, masyarakat diharapkan mampu menerima segala perubahan atas segala hal dalam rangka pengembangan Kawasan Selingkar Wilis (Mahardhani, 2017).

Table 2. Potensi Sumber Daya Alam Ponorogo

\begin{tabular}{|c|c|c|c|}
\hline Sumber Daya Alam & Area Pemandangan & Sumber Daya Alam & Area Pemandangan \\
\hline $\begin{array}{l}\text { Telaga Ngebel } \\
\text { Lokasi: Kecamatan } \\
\text { Ngeberl }\end{array}$ & $y^{2}$ & $\begin{array}{l}\text { Air Terjun Coban } \\
\text { Lawe } \\
\text { Lokasi: Kecamatan } \\
\text { Pudak }\end{array}$ & \\
\hline $\begin{array}{l}\text { Air Terjun Ngebel } \\
\text { Lokasi: Kecamatan } \\
\text { Ngebel }\end{array}$ & & $\begin{array}{ll}\text { Lembah } & \text { Tanah } \\
\text { Goyang } & \\
\text { Lokasi: Desa } & \text { Pudak } \\
\text { Wetan } & \end{array}$ & \\
\hline $\begin{array}{l}\text { Watu Semaur } \\
\text { Lokasi: Kecamatan } \\
\text { Ngrayun }\end{array}$ & & $\begin{array}{l}\text { Kedung Kethus) } \\
\text { Lokasi: Kecamatan } \\
\text { Ngambong Jenangan }\end{array}$ & \\
\hline
\end{tabular}




\begin{tabular}{|c|c|c|c|}
\hline $\begin{array}{l}\text { Gunyng Gajah } \\
\text { Lokasi: Kecamatan } \\
\text { Sambit }\end{array}$ & 85 & $\begin{array}{l}\text { Curug Pitu } \\
\text { Lokasi: Desa Baosan } \\
\text { Kidul, Kecamatan } \\
\text { Ngrayun }\end{array}$ & 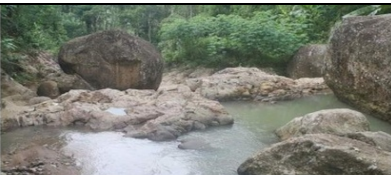 \\
\hline $\begin{array}{l}\text { Bukit Teletubbies } \\
\text { Lokasi: Kecamatan } \\
\text { Balong }\end{array}$ & & $\begin{array}{l}\text { Air Terjun Pletuk } \\
\text { Lokasi: Kecamatan } \\
\text { Sooko }\end{array}$ & \\
\hline $\begin{array}{l}\text { Goa Lowo } \\
\text { Lokasi : Hutan Jati } \\
\text { Desa Boworejo, } \\
\text { Kecamatan } \\
\text { Sampung }\end{array}$ & 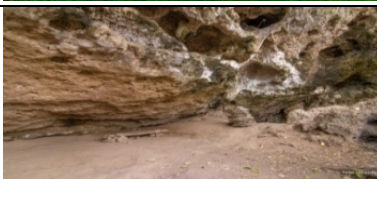 & $\begin{array}{l}\text { Kaki Gunung Bedes } \\
\text { Lokasi: r Desa } \\
\text { Ngadirojo Kecamatan } \\
\text { Sooko }\end{array}$ & \\
\hline $\begin{array}{lr}\text { Pemandian } & \text { Air } \\
\text { Hangat } & \text { Tirto } \\
\text { Husono } & \\
\text { Lokasi: Kecamatan } \\
\text { Ngebel }\end{array}$ & 20 & $\begin{array}{l}\text { Watu Putih } \\
\text { Lokasi: Kecamatan } \\
\text { Ngrayun }\end{array}$ & \\
\hline
\end{tabular}

Sumber: Hilman, 2016.

Selain Reog dan Grebeg Suro, potensi wilayah yang di miliki oleh Kabupaten Ponorogo sangatlah beragam. Potensi tersebut objek wisata alam, yang antara lain adalah Telaga Ngebel. Telaga ini merupakan sebuah danau yang terbentuk secara alami. Di sekeliling Telaga Ngebel terdapat hutan yang ditumbuhi pohon-pohon tinggi dan lebat. Air telaga yang tenang dan cukup luas, ditambah udara yang sejuk serta pemandangan hutan yang hijau di sekelilingnya membuat siapa pun akan kagum melihatnya. Hal inilah yang menjadi salah satu daya tarik dari obyek wisata Telaga Ngebel untuk dikunjungi. Dibandingkan obyek wisata alam lainnya yang ada di Kabupaten Ponorogo, Telaga Ngebel mempunyai potensi dan daya tarik yang tinggi untuk dikembangkan. Dilihat dari jumlah sarana fasilitas pendukung wisata, Telaga Ngebel lebih lengkap dibandingkan obyek wisata alam lainnya. Dari sisi jumlah kunjungan wisatawan, Telaga Ngebel juga yang paling banyak dibandingkan lainnya. Hal inilah yang menjadikan obyek wisata Telaga Ngebel sebagai obyek wisata alam andalan di Kabupaten Ponorogo (Rahman \& Prakoso, 2012).

Selain potensi alam, tersedia kuliner khas Ponorogo, yaitu sate ayam. Sate Ponorogo adalah sate yang berasal dari Ponorogo Jawa Timur. Sate ini terbuat dari daging ayam, tidak seperti sate pada umumnya, potongan daging pada sate ini tidak dipotong dadu melainkan disayat tipis seperti fillet. Proses membumbui sate ini dengan direndam melalui proses bacem (Nufus, Juwaedah, \& Setiawati, 2016). Terhadap makanan kuliner lokal ini, Pemerintah Daerah Ponorogo ikut serta memberikan pengarahan dan penyuluhan kepada kuliner lokal industri sate ayam Ponorogo agar tetap menjadi makanan khas Kabupaten Ponorogo. Pemerintah Daerah Ponorogo telah melakukan perlindungan hak paten industri sate ayam di Kabupaten Ponorogo. Hak paten tersebut berupa izin dagang yang sudah dimiliki oleh industri sate ayam Ponorogo. Pemerintah Daerah Ponorogo juga memberikan keterangan industri sentral sate ayam pada industri sate ayam di gang sate Kelurahan Nologaten Kabupaten Ponorogo (Wardani \& Djuwitaningsih, 2017).

\subsection{Event Pariwisata di Kabupaten Ponorogo}

Penyelenggaraan perayaan Grebeg Suro merupakan moment penting bagi masyarakat dalam maupun luar Ponorogo. Disamping sebagai barometer perkembangan seni budaya, perayaan Grebeg Suro tersebut juga merupakan indikator kepedulian Pemerintah Kabupaten Ponorogo terhadap persoalan sosial ekonomi dan budaya masyarakat Ponorogo. Adapun alasan 
penyelenggaraan perayaan Grebeg Suro adalah 1) Upaya melestarikan, mengembangkan dan meningkatkan mutu kesenian Reog Ponorogo sebagai asset Budaya Nasional. 2) Menunjang Program Pemerintah, khususnya Bidang Kepariwisataan di Kabupaten Ponorogo. 3) Memperingati Tahun baru Hijriah 1 Muharram $1434 \mathrm{H}$ setiap tahun. 4) Meningkatkan perekonomian masyarakat Ponorogo sebagai dampak multiplier effect dari penyelenggaraan Grebeg Suro (Wahjuni, 2015).

Grebeg Suro yang dulu merupakan acara yang sederhana dan sakral akan nilai-nilai tradisi, kini mulai kehilangan hal tersebut dengan banyak menampilkan unsur entertainment dari pada kebudayaannya. Hal tersebut memicu adanya protes dari para budayawan karena dinilai sudah ada unsur kepentingan beberapa pihak di dalamnya. Pertentangan kepentingan itu antara lain adanya kepentingan pemerintah untuk mengarahkan Grebeg Suro menjadi sebuah bisnis. Dalam kasus ini, aktor yang berkuasa telah melakukan intervensi terhadap aktor yang menolak pembanguan Grebeg Suro kearah bisnis. Intervensi dilakukan dengan bentuk ketidakadilan dalam rencana Grebeg Suro yang diselenggarakan tidak partisipatif serta terjadi manipulasi dalam prosesnya. Selain itu, masyarakat yang menolak mengalami intervensi juga dalam wujud terbatasnya akses dalam penyediaan lokasi untuk berdagang.

Pengembangan Grebeg Suro ke arah bisnis dilakukan pemerintah dengan bekerja sama dengan pihak swasta yaitu EO (event organizer) dalam satu hubungan bisnis. Tidak hanya itu, mayoritas elit politik turut mendukung pemerintah, termasuk masyarakat juga menikmati Grebeg Suro dan tidak mempedulikan lagi bahwa ada manipulasi dan penggerusan nilai-nilai kebudayaan sedikit demi sedikit. Dengan pemikiran tersebut pemerintah ingin membawa Grebeg Suro lebih ke arah bisnis yang lebih berorientasi ekonomi dibanding pelestarian budaya. Pemerintah agaknya lupa bahwa kebudayaan semestinya harus tetap dijaga, hubungan baik dengan budayawan dan pelaku-pelaku seni juga harus tetap dijaga agar tetap tercipta stabilitas di dalamnya (Fakhriza, 2016).

Perputaran uang selama gelaran Grebeg Suro di Kabupaten Ponorogo tahun 2018 diperkirakan mencapai Rp10 miliar lebih. Perputaran berasal dari transaksi sektor jasa, perhotelan, transportasi hingga usaha mikro, kecil, dan menengah (UMKM). Wakil Bupati Ponorogo Soedjarno mengatakan, selain bertujuan pelestarian budaya, Grebeg Suro yang merupakan gelaran tahunan ini juga diharapkan mampu mendongkrak ekonomi kerakyatan. Grebeg Suro sendiri pelaksanaannya dibarengkan dengan Perayaan Hari Jadi Ponorogo ke-522 yang jatuh pada 12 Agustus. Hal ini demi efisiensi dan efektifitas kegiatan tahunan. "Semua dagangan laku kalau ada Grebeg Suro. Masyarakat menyambut acara ini dengan sangat antusias. Pengunjung tidak hanya dari Ponorogo, tapi juga dari luar Ponorogo. Bahkan hotel-hotel okupansinya penuh semua," ujarnya usai menyaksikan Parade Budaya di depan Kantor Pemkab Ponorogo (sindonews.com, 2018).

Meskipun penuh kontroversi dan perdebatan, iven Grebeg Suri telah menjadi iven tahunan penting di Ponorogo dan menyumbang terhadap sektor ekonomi riil. Hal ini terbukti dari kontribusinya dalam meningkatkan jumlah pengunjung yang datang dan membeli tiket. Selain itu dampaknya dapat meningkatkan pemasukan ekonomi daerah dari berbagai jenis retribusi dan juga penjuan tiket, sehingga peluang ini bisa terus digali supaya bisa lebih maksimal. Oleh karena itu, grebeg Suro sangat berpotensi atau berpeluang dimaksimalkan sebagai atraksi wisata tanpa mengabaikan nilainilai luhur yang terkandung di dalamnya.

\subsection{Inovasi dan Kelembagaan Pariwisata Kabupaten Ponorogo}

Obyek wisata budaya, alam, kuliner, dan lainnya menjadi potensi unggulan yang dapat dijadikan sebagai destinasi kabupaten Ponorogo. Namun demikian, kabupaten ini terus berkembang dan juga selalu melakukan inovasi untuk meningkatkan jumlah kunjungan wisatawan. Sebagai upaya nyata dan sadar dalam rangka optimalisasi sektor pariwisata. Menurut Lilik Slamet Raharjo, kepala dinas Pariwisata Kabupaten Ponorogo, untuk meningkatkan minat wisatawan berkunjung 
ke Ponorogo, akan dilakukan berbagai iven atau festifal Topeng Internasional sebagai salah satu iven besar lain setelah Grebeg Suro (Ponorogo Pos, 2018).

Selain inovasi tersebut, untuk upaya peningkatan kunjungan wisatawan, Kabupaten Ponorogo juga telah memiliki payung hukum berupa Peraturan Bupati Ponorogo nomor 48 tahun 2017 tentang Pedoman Penetapan Desa Wisata. Adanya aturan ini menunjukkan bahwa Pemerintah Kabupaten Ponorogo serius mengembangkan pariwisata yang ada di wilayahnya. Hingga saat ini kabupaten Ponorogo telah memiliki kurang lebih sekitar 20 desa wisata yang tersebar di 11 kecamatan.

Tabel 3 Daftar Nama Desa Wisata Calon Penerima Tahun Anggaran 2018

\begin{tabular}{|c|c|c|c|}
\hline \multirow[b]{2}{*}{ Program/Kegiatan } & \multicolumn{3}{|c|}{ Calon Penerima } \\
\hline & Nama Desa & $\begin{array}{l}\text { Keca } \\
\text { matan }\end{array}$ & Pagu \\
\hline Desa Wisata Makam Bupati Gading & Slahung & Slahung & Rp 25.000.000.00 \\
\hline $\begin{array}{l}\text { Desa Wisata Puncak pertapaan, Grojogan Dung } \\
\text { Oleng, Watu Bon }\end{array}$ & Wates & Slahung & Rp 25.000.000.00 \\
\hline Desa Wisata Pemandian Jendral Sudirman & Munggung & Pulung & Rp 25.000.000.00 \\
\hline Desa Wisata Tubing Mendak lereng Wilis & Wagir Lor & Pulung & $\operatorname{Rp} 25.000 .000 .00$ \\
\hline Desa Wisata Arum Jeram anak & Kesugihan & Pulung & $\operatorname{Rp} 25.000 .000 .00$ \\
\hline Desa Wisata Goa Pertanda, Gunung Dloko & Tatung & Balong & $\operatorname{Rp} 25.000 .000 .00$ \\
\hline $\begin{array}{l}\text { Desa Wisata Gunung Masjid, Air Terjun Watu } \\
\text { Tawang }\end{array}$ & Pandak & Balong & Rp 25.000.000.00 \\
\hline Desa Sendang Beji, Arum jeram sungai kajar - kajar & Paringan & Jenangan & Rp 25.000.000.00 \\
\hline $\begin{array}{l}\text { Desa wisata grojogan kokok, Goa Dasar sungai bawah } \\
\text { tanah, gunung baying kaki, air terjun selorejo }\end{array}$ & Temon & Sawoo & Rp 25.000.000.00 \\
\hline $\begin{array}{l}\text { Desa Wisata Makam ki Ageng Imam Puro, Kebo - } \\
\text { keboan }\end{array}$ & Sukosari & Babadan & Rp 25.000.000.00 \\
\hline Desa Wisata coban pelangi & $\begin{array}{l}\text { Tumpak } \\
\text { Pelem }\end{array}$ & Sawoo & $\operatorname{Rp} 25.000 .000 .00$ \\
\hline Desa Wisata Jurug Carat dan Hutan Lestari & Mrayan & Ngerayun & Rp 25.000.000.00 \\
\hline $\begin{array}{l}\text { Desa Wisata Panorama alam baras, Jurang Gandul, } \\
\text { Tapak Kebo, Bukit Siluman }\end{array}$ & Blaosan Lor & Ngerayun & Rp 25.000.000.00 \\
\hline Desa Wisata Jurug Pito & Blaosan Kidul & Ngerayun & $\operatorname{Rp} 25.000 .000 .00$ \\
\hline Desa Wisata Astana Srandil & Srandil & Jambon & Rp 25.000.000.00 \\
\hline Desa Wisata Watu Pecah, Air Terjun Dung Lodok & Jonggol & Jambon & Rp 25.000.000.00 \\
\hline Desa Wisata Air Terjun Bedrek & Sidoharjo & Jambon & Rp 25.000.000.00 \\
\hline Desa Wisata Sendang Beji & Ngelurup & Sampung & Rp 25.000.000.00 \\
\hline Desa Wisata Situs Watu Dukun, Grojogan Ngrejeng & Pagerukir & Sampung & Rp 25.000.000.00 \\
\hline $\begin{array}{l}\text { Desa Wisata Beji Siran Keteng, Tanah Gemplah } \\
\text { sungai Bawah Tanah }\end{array}$ & Bedingin & Sambit & Rp 25.000.000.00 \\
\hline
\end{tabular}

Sumber: bappeda.ponorogo.go.id, 2018

Adanya inovasi dan kebijakan pengembangan desa wisata di Ponorogo, memperlihatkan bahwa Kabupaten Ponorogo serius mengambangkan sektro wisata. Tidak hanya dalam bentuk kebijakan, pemerintah juga telah mengalokasikan dana bagi penguatan kelembagaan Desa Wisata sebagai Penopang wisata daerah. Dengan memberikan pendanaan tersebut, pemerintah berupaya memotivasi Desa supaya bisa mengoptimalkan potensi yang dimiliki untuk membangun desa wisata yang kuat, berkesinambungan. Namun demikian terdapat ancaman terkait bagaimana desa itu mengelola dana yang diperoleh dari pemerintah kabupaten, serta bagaimana model pertanggungjawabanya, menjadi persoalan tersendiri dalam tataran teknisnya di tingkat pemerintah desa. 


\section{Diskusi dan Kesimpulan}

Pembahasan sebagaimana dijelaskan di atas memperlihatkan bahwa kelembagaan pariwisata di Kabupaten Ponorogo memiliki berbagai kekuatan, kelemahan, peluang dan ancaman. Kekuatan atau strength dari Wisata yang ada di Kabupaten Ponorogo terletak pada berbagai varian potensi yang dimiliki, meliputi potensi alam, budaya, kesenian, gastronomi, dan juga religi. Kekuatan tersebut nampaknya telah disadari dengan baik oleh pemerintah dan juga masyarakat, sehingga berbagai upaya terus dilakukan.

Kelemahan atau weakness dari Wisata di Kabupaten Ponorogo adalah dalam inovasi penyelenggaraan iven, karena hal tersebut merupakan sesuatu yang baru. Ketika dilaksanakan bisa saja terjadi kesalahan atau kekurangan dalam praktiknya, namun demikian Pemerintah Kabupaten Ponorogo sepertinya sudah mampu menyelenggarakan iven sebanyak sejumlah 66 kali dengan baik, termasuk festival internasional topeng (Internasional Foklore Fest). Dengan demikian kelemahan yang diprediksi tersebut menjadi sebuah kekuatan yang dapat dijadikan sebagai kejutan bagi para wisatawan yang berkunjung. Terlebih lagi terselenggaranya berbagai iven tersebut dapat menjadi sebuah peluang dengan munculnya sumber-sumber pendapatan baru, dari berbagai retribusi dan juga penjualan tiket masuk dalam kegiatan tahunan kunjungan wisata. Dengan demikian, kelemahan yang ditakutkan menjadi peluang untuk dikembangkan.

Adanya dana untuk pengembangan desa wisatana adalah hal yang sensitif, sehingga perlu adanya landasan atau dasar hukum yang kuat dalam mengatur pengelolaan, penggunaan dan juga mekanisme pertanggungjawabanya keuangan. Agar tidak menimbulkan keresahan, Kabupaten Ponorogo telah mengeluarkan perda terkait hal tersebut, sehingga aturan yang tertuang dalam Peraturan Bupati Ponorogo nomor 48 tahun 2017 tentang Pedoman Penetapan Desa Wisata bisa menjadi landasar dan pedoman.

Pemerintah Kabupaten Ponorogo telah mampu menyelenggarakan iven tahun Kunjungan wisata tahun 2019, dengan Tajuk "Dolan Ponorogo". Hal tersebut terlihat dari pemahaman kekuatan berupa potensi alam, budaya, kesenian, religi, dan juga gastronomi yang dimiliki. Kemudian, Kabupaten Ponorogo juga telah mampu mengatasi masalah, hambatan atau ancaman dengan melakukan berbagai upaya secara kelembagaan dan juga inovasi. Dengan demikian, berbagai hal yang awalnya menjadi persoalan, bisa diubah menjadi kekuatan lain atau senjata andalan baru dalam memperkuat kelembagaan wisata di Kabupaten Ponorogo

\section{Ucapan Terimakasih}

Terima kasih kepada Program Studi Ilmu Pemerintahan, FISIP, Universitas Muhammadiyah Ponorogo yang telah mendukung penelitian ini hingga selesai, kami juga mengucapkan terimakasih kepada Pemerintah Kabupaten Ponorogo yang telah memberikan ijin untuk melakukan penelitian di wilayah nya, tidak lupa saya sampaikan ucapan terimakasih terhadap kesediaan penulis kedua untuk membantu kelancaran dalam penyusunan artikel ilmiah ini

\section{Pendanaan}

Kajian ini merupakan penelitian yang tidak mendapatkan biaya dari lembaga manapun. Penelitian dibiayai secara mandiri oleh penulis.

\section{Konflik Kepentingan}

Yusuf Adam Hilman sebagai penulis pertama menyatakan bahwa tidak ada konflik kepentingan dengan Titing Kartika sebagai penulis kedua terhadap naskah tersebut.

\section{References}

Aliyah, I., Nugroho, P. S., \& Yudana, G. (2014). Model Pengembangan Kawasan Penangkaran Burung Merak Untuk Mendukung Revitalisasi Pariwisata Di Kabupaten Ponorogo. Journal 
of Rural and Development, 5(2), 129-146.

Anggraeni, A. A. (2013). Analisis Dampak Ekonomi Wisata Bahari terhadap Pendapatan Masyarakat di Pulau Tidung. Reka Loka, 1(1), 1-8.

Astuti, W. P., \& Kusumawati, A. (2018). Upaya Pemasaran Pariwisata Ponorogo Melalui City Branding dalam Meningkatkan Kunjungan Wisatawan (Studi Kasus pada City Branding Kabupaten Ponorogo dengan Tagline " Ethnic Art of Java"). Jurnal Administrasi Bisnis, 55(1), 48-58.

bappeda.ponorogo.go.id. (2018). Daftar Nama Desa Wisata Calon Penerima Tahun Anggaran Tahun 2018. Retrieved from https://bappeda.ponorogo.go.id/index.php/datainfo/dokumen-perencanaan/item/246-daftar-nama-desa-wisata

detik.com. (2018a). Penerimaan Perpajakan 2017 Capai Rp 1.339 Triliun, 91\% dari Target. Retrieved from https://finance.detik.com/berita-ekonomi-bisnis/d-3795760/penerimaanperpajakan-2017-capai-rp-1339-triliun-91-dari-target

detik.com. (2018b). Sebut Ekonomi RI Sakit, Rizal Ramli: Menteri Jokowi Sibuk Bantah. Retrieved September 23, 2018, from https://finance.detik.com/energi/d-4144979/sebutekonomi-ri-sakit-rizal-ramli-menteri-jokowi-sibuk-bantah

Fakhriza, N. Z. (2016). Perubahan Kebijakan Ritual Grebeg Suro di Kabupaten Ponorogo dalam Teori Orientasi Aktor Abstrak Pendahuluan Penelitian tentang orientasi aktor dalam perubahan Kebijakan ritual Grebeg Suro ini didasari pemikiran sebagai berikut : ( 1 ) bahwa sebuah proses. Politik Muda, 6(1).

Firdaus, F., \& Tutri, R. (2017). Potensi Pengembangan Ekowisata Di Nagari Kotobaru, Kecamatan X Koto, Kabupaten Tanah Datar, Sumatera Barat. Jurnal Kawistara, 7(2), 115206. https://doi.org/10.22146/kawistara. 13570

Flamin, A., \& Asnaryati. (2013). Potensi Ekowisata dan Strategi Pengembangan Tahura Nipa. Jurnal Penelitian Kehutanan Wallacea, 2(2), 154-168.

Hermawan, H. (2016a). Dampak Pengembangan Desa Wisata Nglanggeran Terhadap Ekonomi Masyarakat Lokal. Jurnal Pariwisata, 3(2), 105-117.

Hermawan, H. (2016b). Dampak pengembangan desa wisata nglanggeran terhadap sosial budaya masyarakat lokal. In Seminar Nasional Ilmu Pengetahuan dan Teknologi Komputer (SNIPTek) Nusa Mandiri (pp. 60-70). Jakarta: STMIK Nusa Mandiri.

Hidayat, M. (2011). Strategi Perencanaan Dan Pengembangan Objek Wisata (Studi Kasus Pantai Pangandaran Kabupaten Ciamis Jawa Barat). Tourism and Hospital Essential (THE), I(1), 3344. https://doi.org/10.17509/thej.v1i1.1879

Hilman, Y. A. (2016). Regional Development of Tourism in Ponorogo Regency, East Java. Journal of Indonesian Tourism and Development Studies, 4(4), 91-96. https://doi.org/10.21776/ub.jitode.2016.004.03.01

Hilman, Y. A. (2017). Kelembagaan Kebijakan Pariwisata di Level Desa. JIP (Jurnal Ilmu Pemerintahan), 2(2), 150-163. https://doi.org/10.24905/jip.2.2.2017.150-163

Ikawira, E. Y., Fianto, A. Y. A., \& Sutrisno, A. A. (2014). Penciptaan Buku Ilustrasi Legend Reog Ponorogo Sebagai Upaya Mengenalkan Budaya Lokal Kepada Anak-Anak. Art Nouveau, 3(1).

Jupir, M. M. (2013). Implementasi Kebijakan Pariwisata Berbasis Kearifan Lokal (Studi di Kabupaten Manggarai Barat). Journal of Indonesian Tourism and Development Studies, 1(1), 2837.

Kadir W, A., Nurhaedah, \& Purwanti, R. (2013). Konflik Pada Kawasan Taman Nasional Bantimurung Bulusaraung Provinsi Sulawesi Selatan Dan Upaya Penyelesaiannya. Penelitian SOsial Dan Ekonomi Kehutanan, 10(3), 186-198.

Khoirurrosyidin. (2018). Perayaan Grebeg Suro sebagai Potensi Pengembangan Sektor Wisata Budaya Ponorogo. Aristo, 6(2), 343-353. https://doi.org/10.24269/ars.v6i2.1027 
Kristin, R., \& Salam, R. (2016). Peran Pemerintah Daerah dalam Pengembangan Pariwisata Alam dan Budaya di Kabupaten Tapanuli Utara. Ilmu Pemerintahan Dan Sosial Politik, 4(1), 79-96.

Kuhaja, T. (2014). Kajian Kelembagaan dalam Pengembangan Pariwisata Pantai yang Berkelanjutan. Jurnal Pembangunan Wilayah \& Kota, 10(3), 278-292. https://doi.org/10.14710/pwk.v10i3.7785

Mahardhani, A. J. (2017). Peran Pemerintah Kabupaten Ponorogo Dalam Pengembangan Kawasan Selingkar Wilis, 437-447.

Nizar, M. A. (2015). Tourism Effect On Economic Grwoth In Indonesia. In MPRA (Munich Personal RePEc Archive.

Nufus, N., Juwaedah, A., \& Setiawati, T. (2016). Analisis Hasil Belajar "Mengolah Hidangan Sate atau Jenis Makanan Yang Dipanggang" Pada Kesiapan Membuka Usaha Siswa. Media Pendidikan Gizi Dan Kuliner, 5(2), 60-71.

okezone.com. (2018). Amerika vs China: Pertempuran demi Masa Depan Ekonomi. Retrieved September 23, 2018, from https://economy.okezone.com/read/2018/07/02/20/1916893/amerika-vs-chinapertempuran-demi-masa-depan-ekonomi

Ponorogo Pos. (2018). Kabupaten Ponorogo Mengadakan Festifal Topeng dan Foklore Internasional. Edisi 840, TH XVII, 04 - 10 Oktober 2018.

Pontoh, O. (2011). Peranan Nelayan Terhadap Rehabilitasi Ekosistem Hutan Bakau (Mangrove). Perikanan Dan Kelautan Tropis, 7(2), 73-79.

Pralina, C. Y., \& Sujali. (2009). Keterkaitan Pariwisata Terhadap Pembangunan Manusia Di Jawa Tengah Tahun 2004-2009. Bumi Indonesia, 1(2), 49-57.

Pramudita, P. S., \& Herdiana, I. (2012). Dampak Psikososial Pada Anak Jalanan Korban Pelecehan Seksual Yang Tinggal di Liponsos Anak Surabaya. Psikologi Kepribadian Dan Sosial, 1(2), 68-72.

Pujiati, O., \& Hatmawan, A. A. (2017). Optimalisasi Potensi Ekonomi Festival Reog Ponorogo Dan Dampaknya Terhadap Pendapatan Asli Daerah. In Prosiding Seminar Nasional Hasil Penelitian (pp. 296-302).

Rahman, N., \& Prakoso, H. B. S. E. (2012). Perspektif Stakeholders Terhadap Potensi Obyek Dan Daya Tarik Wisata (ODTW) Telaga Ngebel Kabupaten Ponorogo. Jurnal Bumi Indonesia, 1(1).

Siahaan, S. L. (2008). Visit Indonesia Year 2008: Suatu Tinjauan dari Perspektif Pemasaran Destinasi Pariwisata. Majalah Ilmiah Panorama Nusantara, 7-15.

Wahjuni, E. (2015). Hegemoni Pemerintah Daerah Dalam Penyelenggaraan Grebeg Suro Masyarakat Ponorogo. Aristo, 3(2), 46-53.

Wardani, T. P., \& Djuwitaningsih, E. W. (2017). Peran Pemerintah Daerah Terhadap Eksistensi Industri Sate Ayam Dalam Persaingan Kuliner Fast Food (Studi kasus: Sentral Industri Sate Ayam Kelurahan Nologaten Kabupaten Ponorogo). Indonesian Journal Of Governance and Communications Studies, 1(1), 92-102.

Yoserizal, \& Yudiatmaja, W. E. (2010). Strategi Pemerintah Provinsi Sumatera Barat dalam mengembangkan e-government sebagai upaya peningkatan kualitas pelayanan publik. JIANA (Jurnal Ilmu Administrasi Negara), 10(1), 89-100.

Yuli, A. (2011). City Branding Sebagai Strategi Pengembangan Pariwisata Ditinjau Dari Aspek Hukum Merek (Studi Kasus City Branding Daerah Istimewa Yogyakarta Sebagai Daerah Tujuan Wisata Unggulan Di Indonesia). Qistie : Jurnal Ilmu Hukum, 5(1), 50-68.

Zakaria, F., \& Suprihardjo, R. D. (2014). Konsep Pengembangan Kawasan Desa Wisata di Desa Bandungan Kecamatan Pakong Kabupaten Pamekasan. Teknik Pomits, 3(2). 